\title{
Towards State Hegemony Over Agricultural Certification: From Voluntary Private to Mandatory State Regimes on Palm Oil in Indonesia
}

\author{
Muhammad Alif Kaimuddin Sahide ${ }^{1 *}$, Sarah Burns ${ }^{1}$, Agung Wibowo ${ }^{1}$, Dodik Ridho Nurrochmat', \\ Lukas Giessen ${ }^{1}$
}

\author{
'Chair of Forest and Nature Conservation Policy, Georg-August-Universität Goettingen, \\ Buesgenweg 3, Goettingen, Germany, 37077 \\ ${ }^{2}$ Department of Forest Management, Faculty of Forestry, Bogor Agricultural University, Academic Ring Road \\ Campus IPB Dramaga, PO Box 168, Bogor, Indonesia 16680
}

Received October 20, 2015/Accepted November 28, 2015

\begin{abstract}
Previous work on certification of palm oil has reported on a trend toward a change, from failed state regulation to voluntary, private governance. However, recent observations suggest a trend, moving from voluntary, private governance to mandatory state governance in palm oil certification in Indonesia, a move in which the state is reclaiming authority. In this light, the aims of our research are (1) to identify the main actors involved in certification politics, (2) to explain this trend in terms of the actors' interests and whatever benefits may result for them. We developed our research questions based on bureaucratic politics and power theory. A mix of document analysis, interviews, and observations are applied for addressing the questions. The results answer our research questions, i.e., that (1) the state claims back its authority over certification from private actors and contributed to the complex meta governance of palm oil certification, the state mandatory scheme that is supported by states' bureaucracies in charge reduces the influence of non-government or private actors. (2) This trend is due to a coalition of specific state bureaucracies and big industry interests, which grant privileges to industry that are denied to small producers. Unexpectedly, all Indonesian bureaucracies associated with this trend support mandatory state certification, which indicates that palm oil has been elevated in importance to become a matter of national, rather than mere bureaucratic interest. Making certification mandatory through coercive regulatory power is the main tool with which state power can challenge voluntary implementation and reclaim authority. Furthermore, the state needs the voluntary system to exist as well in order to strengthen its position. Therefore, the voluntary and the compulsory systems collaborate to attract global initiatives, which is contributing to the high complex of meta governance.
\end{abstract}

Keywords: international regimes, transnational regimes, RSPO, ISPO, meta governance, palm oil, Indonesia

*Correspondence author, email:alif.mksr@gmail.com,ph. :+49-551-3913391

\section{Introduction}

Private certification was introduced in the early 1990s to address concerns associated with environmental issues, especially in the tropics (Rametsteiner \& Simula, 2003), for many commodities (Blackman \& Rivera, 2011). The increased participation by non-state actors through these mechanisms gave way to transnational regimes, differing from state driven international regimes (Pattberg 2012). Transnational regimes include many different issue areas, one example being palm oil certification. The Roundtable on Sustainable Palm Oil (RSPO) is used widely as a reference for private palm oil plantation certification in Indonesia, covering both food and fuel uses (Larsen et al. 2014). Palm oil plantations and its industrial sector play an indispensable role for the Indonesian economy bringing more than \$21 billion per year in export earnings (Agrofarm 2013b).
Currently, the Indonesian government experiments with state mandatory schemes, through the establishment of the Indonesian Sustainable Palm Oil (ISPO) certification (Edwards \& Laurance 2012). A similar transformation from voluntary-private to mandatory-public authority also exists with soybean in Brazil (Hospes 2014) and timber products (Cashore \& Stone 2012, Giessen et al. 2015, Pratiwi et al. 2015, Wibowo et al. 2015). The political consequences of the re-establishment of national governance in certification processes have generated several research topics, such as the politics of scaling (Hospes \& Kentin 2014), dynamic interactions (Gulbrandsen 2014), intersection (Cashore \& Stone 2012) and contested legitimacy (Marin-Burgos et al. 2014).

However, there is not enough research in the area to assess state actors' interests in reclaiming their authority, 
especially in the single case of palm oil certification. Therefore, we will explore the interests among the actors of these regulatory (ISPO) and voluntary (RSPO) certification regimes using a bureaucratic (state and non-state) political theory approach that is based on the utility production of these two schemes. Therefore, the aims of this research are (1) to identify the main actors involved in certification politics, and (2) to explain this trend by examining actors' interests and the resulting benefits for them.

\section{Theoretical background}

Voluntary private certification Transnational regimes can be defined as "set of norms, rules, and decision-making procedures that are made and implemented across borders through the activities of non-state actors" (Pattberg 2012) differing from international regimes where the states generate the rules (Pattberg 2012). International schemes, as certification, can then be described as transnational regimes which aim to enable the market to control and to select products that comply with quality assurance, offering at the same time greater incentives for industries to implement environmentally and socially responsible objectives (Cashore 2002; McCarthy 2012). This non-state governance has created non-state, market-driven (NSMD), governance systems (Cashore 2002). Cashore et al. (2007) argued that "the most important feature of NSMD governance is that there is no use of state sovereignty to enforce compliance". However, Sikor et al. (2013) found that new forms of social exclusion, inequity, and ecological simplification have been generated from flow-centred governance, due to the intensive competition for land (including global certification).

McCarthy (2012) analysed the regulation of the palm oil boom in Indonesia, where the RSPO certification system is widely influential, as well as the International Organization for Standardizations (ISO) 14001 series for environmental management systems. Hospes (2014) found that the difficulties in the implementation of this voluntary private standard at the domestic level (in the South) have prompted the collaboration of scholars with national or local governments. The RSPO also provides open space for social and environmental NGOs on their membership board and multi-stakeholder initiatives. Pesqueira \& Glasbergen (2013) found that engagement in non-state governance processes gives NGOs valuable advantages, since they contribute to areas to which governments are unwilling or incapable of doing likewise, offering a synergistic and innovative relationship for the creation of benchmarks that can introduce significant changes to current practice, and that encompass sector-wide interventions offering a broader potential for change than collaboration with individual interventions. Busch (2014) argued that this is evidence of both the continuing hegemony of neoliberalism and of various responses to it.

Meta governance: the experiment of mandatory state certification due to bureaucratic politics Currently, a shift towards state certification is observed, suggesting that in pursue of their formal mandates and informal interests state bureaucracies like the Ministry of Agriculture (MoA) and
Ministry of Trade (MoT) formally strive for better economic performance by national palm oil industries while at the same time extending their policy domains where they operate, gaining legitimacy, staff and budget. We define the interests of bureaucracies as their search for problem-oriented delivery of public service, and their pursuit of the organisational interests of survival and organisational expansion (Weber 1922; Niskanen 1971; Krott 2005; Peters 2010). A distinctive feature of these bureaucratic politics approach is that bureaucracies in their behaviour follow a dual organizational interest: (1) informally they are competing with other actors and especially other bureaucracies for resources, political domains and influence, and (2) formally, they have distinct tasks for delivering public services. In addition, bureaucray will use their power to reclaim their authority (Giessen et al. 2014). In addition, bureaucracies will use their power to reclaim their authority.

However, Following this Weberian approach focusing on bureaucracy and state power has still limitation, this perspective does not grasp the issue of bureaucratic actors operating in their private capacity (e.g. receiving patronage, placing themselves in flows of revenue) (Aspinall \& van Klinken 2011), particularly for the very complex situation and land use administration in Indonesia (Sahide \& Giessen 2011). Therefore, this actor centred perspective will take into account the informal private interests of bureaucrats, as well as bureaucracies.

We followed this line of argumentation by looking into how the experiment of mandatory public governance reclaims back its authority from the failed global governance of voluntary private certification, which is resulted to the meta-governance due to the high politic of their intersections from both private and state certifications. We define this mandatory public governance as experiment at the moment, as state bureaucracies do not know yet if credibility from NSMD certification also works for state led certification, which only markets will show in the future. Overdevest and Zeitlin (2014) argue that experimentalism provides an analytical framework for evaluating transnational governance interactions in regime complexes where the scope for this experimentalist governance is precisely the opposite of those for regime formation in standard international relations (the regime concept can be seen in section 2.3.)

Mandatory state certification is introduced through legal state verification schemes (Pratiwi et al. 2015). This legality can be confirmed by creating formal connections with domestic rules (Schouten \& Glasbergen 2011). This scheme is mystifying because it presents a relatively modest solution, compared to previous efforts to build a legally-binding global-private certification system, and yet it is garnering the interest of a wide range of diverse global coalitions within developed and developing countries (Cashore \& Stone 2012). The ISPO system is a policy adopted by the Ministry of Agriculture on behalf of the Government of Indonesia and was mandatory from the beginning for all palm oil firms operating in Indonesia (MoA Regulation 19 of 2011). The aim of the ISPO is "to improve the competitiveness of the Indonesian palm oil on the global market and contribute to the objective set by the President of the Republic of 
Indonesia to reduce greenhouse gases emissions and draw attention to environmental issues" (ISPO Commission 2013a).

Key research questions Based on the theories above, we develop the following hypotheses around the general assumption that by using certification state bureaucracies claim back authority from private-actors and institutions (Pattberg 2012):

1 Did bureaucracies, for countering private palm oil certification, establish state-driven palm oil certification schemes and useed their regulatory power for even imposing an obligation to certify?

2 How did different bureaucracies favour different certification schemes, e.g. based on bureaucratic interests?. Are the land use bureaucracy in favour of mandatory state schemes whereas the trade bureaucracy favoured private-voluntary schemes?

\section{Methods}

To gain our objectives, content analyses was used. Policy documents, the media or professional journals published by political actors are basic resources for qualitative content analysis that is a flexible method for analysing text data (Hsieh \& Shannon 2005; Neuman 2005). This literature review is used for identifying actors and their positions in certification politics. In addition, interviews to staff from different ministries and institutions that have broad knowledge of private voluntary and state mandatory palm oil certification, such as the MoA, ISPO Commission, RSPO Indonesian office, and the Palm Oil Enterprise Association (GAPKI) were done. The purpose of these selected interviews was to develop a causal explanation to our hypotheses (Mosley 2013). This paper reviews some of the current main actors and provides descriptions of their interests and power bases. We also delivered observations (during December 2013-February 2014) based on van Evera (1997).

This is also supported by interviews and observations in the field. In the end, we examining actors' interests and the resulting benefits for them of both certification schemes and by explaining who is getting privileges as a result from both state coalition and private coalition, as well as their interests intersection, using bureaucratic politic theory.

\section{Results and Discussion}

RSPO-voluntary versus ISPO-mandatory palm oil certification Table 1 shows that private RSPO certification provides tools but cannot address underlying issues that require legal jurisdiction from land use bureaucracies (MoFor, NLA, and Regional Government). This supports McCarty's (2012) argument that certification requires legal reforms.

The RSPO could not introduce their additional criteria for certification, which required companies to go beyond what national law currently requires, because the RSPO does not have a legal orientation (for detailed explanation, it can be seen in Sections The ISPO coalition and RSPO coalition).

\section{The ISPO Coalition}

1 Ministry of Agriculture (and ISPO Commission)

The Ministry of Agriculture (MoA) used its coercive power requiring all palm oil companies in Indonesia to certify under ISPO before 31 December 2014 (MoA Regulation 19 of 2011). The MoA applied the ISPO's principles, indicators and standards, which are nearly the same as the ones from RSPO. However, it does not have full coercive power due to the fragmented Indonesian bureaucracies involved with both land use and commodities (Sahide \& Giessen 2015). The MoA only has the power to lower a company's classification to fourth grade (the worst). The MoA is increasing its staff and budget, benefitting through a new ad hoc commission under MoA authority, the ISPO Commission, in charge of developing ISPO standards and systems. In one example, the ISPO Commission activated a budget (IDR391,734,124 in 2011) under the Directorate on Postharvest and Business Development of the MoA for ISPO activities such as coordination, consultation, socialisation and system improvement (MoA 2011). At present, the Directorate General for Plantation of MoA is also responsible for palm oil

Table 1 Key features of authority on mandatory-state certification and voluntary-private-certification

\begin{tabular}{lll}
\hline & RSPO (Voluntary -private-global certification) & $\begin{array}{l}\text { ISPO (Mandatory-public-national } \\
\text { verification) }\end{array}$ \\
\hline $\begin{array}{l}\text { Role of } \\
\text { government }\end{array}$ & $\begin{array}{l}\text { RSPO do not require adherence to rules. The MoA } \\
\text { recognises RSPO only as a global voluntary scheme. }\end{array}$ & $\begin{array}{l}\text { ISPO formed and governed by MoA } \\
\text { (Sovereign governments decide) }\end{array}$ \\
$\begin{array}{l}\text { Legality } \\
\text { orientation }\end{array}$ & $\begin{array}{l}\text { Legality only applied to maintain transparency in } \\
\text { global market issues }\end{array}$ & $\begin{array}{l}\text { Legality is the main consideration in a group } \\
\text { of rules from many bureaucracies }\end{array}$ \\
$\begin{array}{l}\text { Authority } \\
\text { resources }\end{array}$ & Market based authority \\
$\begin{array}{l}\text { Authorities } \\
\text { struggle } \\
\text { orientation }\end{array}$ & Infiltrate domestic-state's land use authority & State based authority \\
$\begin{array}{l}\text { Degree of } \\
\text { Compliance }\end{array}$ & $\begin{array}{l}\text { Voluntary /principle and criteria developed, basedon } \\
\text { the consensus of membership or actor's power }\end{array}$ & $\begin{array}{l}\text { Infiltrate other countries' trade authority } \\
\text { (through international, regional, and bilateral } \\
\text { regime) } \\
\text { Mandatory/legally binding, developed } \\
\text { originally by state power. }\end{array}$
\end{tabular}

Source: Adapted from Hospes \& Kentin (2014) 
development, which traditionally has had a large budget and staff. Now, the MoA can develop any changes, or adaptations, and can also use a 'multi-stakeholder' approach based on global trends and markets. Furthermore, the MoA has asked the RSPO to accept the ISPO as the complement of the RSPO standard (Antara 2013). To support strong legality issues on palm oil area, MoA has issued MoA Regulation of 2013 on the Guideline of Plantation Businesss. This rules limiting the maximum area of 100 thousand hectares of every company.

2 National Land Agency (NLA)

As one of the core bureaucracies that play indispensable roles in providing land for palm oil plantation (Sahide \& Giessen 2015) as well as NLA rules, it has been set up as one of the major contribution to the legality indicators of the ISPO standard. The NLA will use any legal position to strengthen their domain responsibilities, especially around providing land for plantations, and this will affect the increased budget for any activities related to this issue, particularly activities in the field. For example, the NLA is not regarded as being fully supportive of the implementation of $\mathrm{HCV}$ from the RSPO standard. Employees of a big palm oil company have confirmed that the NLA sent a warning letter to the private palm oil company after the company applied HCV in their area. The NLA argued that all land concession should be managed, otherwise it might be categorised as wasteland, which is against the law. The MoFor support this argument that if the company consider $\mathrm{HCV}$ is a wasteland and then to be open access resources, the problem is how government can guarantee HCV area will work (it assume when $\mathrm{HCV}$ is needed for biodiversity protection) in absent of manager of the land).

3 Ministry of Forestry (MoF)

The MoF rules also contribute to the legality indicator for the ISPO and it plays a substantial role in releasing forest area for palm oil plantations (Sahide \& Giessen 2015). The MoF will benefit from ISPO certification as a legality tool, using it as a reason for increasing their budget to campaign against illegal palm oil plantation activities in forest areas or to campaign so that ISPO certification cannot be considered for planting palm oil in state forest areas based on the legality principles, the MoF will only fully support ISPO implementation challenging RSPO standard implementation, which is inline with Niskanen (1971) that one of the bureaucracy interests is maximizing budget. For example, applying the HCV standard of the RSPO to a given palm oil concession area would lead to it being categorised as wasteland, which is against the Government Regulation 11 of 2010 on Controlling and Using Waste Land. Consequently, the palm oil concession right would be revoked by the National Land Agency (Agrofarm 2014). The RSPO's prohibition against the development of any new plantation after November 2005 by replacing natural forest or areas required to maintain or enhance high conservation value is known controversially within the plantation industry as the "cut-off-date" and goes against the MoF who 'regularly' release state forest area for plantation purposes (MoF 2011; 2012; 2013).

4 Regional Government

The regional government includes important bureaucracies that issue preliminary licences to provide land for palm oil concession (Sahide \& Giessen 2015) They will benefit from the fact that ISPO certification will increase their political responsibilities, and they expect a regional income from palm oil plantations. The regional government comprises the central state actors at the local level that establish the legality element of the ISPO standard.

5 The Ministry of Environment (MoE)

Regulates the spatial planning and Environmental Impact Assessment processes that aim to ensure that the environmental principles are applied to the planning process and that identify and address the anticipated environmental effects of palm oil plantation activities. ISPO provides a complete standard for the production and long term viability of the plantation organisation, but regarding conservation and protection of rare, threatened and endangered species, the ISPO relies on the national environmental assessment, which is governed by the $\mathrm{MoE}$, and become a major legality indicator of the ISPO standard. However, the credibility and capability of assessors on the Environmental Impact Assessment platform are sometimes criticised by non-state actors.

6 Big palm oil producer companies

Big palm oil companies that operate in Indonesia, like PT Bakrie Sumatra Plantation (BSP) and PT London Sumatra Plantation, play important roles because of their dual membership, being registered in both the RSPO membership and the GAPKI, which supports ISPO (RSPO 2012; GAPKI 2013). The basic motive for this is that those companies are in a strategic position to acquire information among the RSPO and ISPO coalitions and to use it to benefit from both schemes.

7 The Ministry of Trade (MoT)

Supports fiscal policies, such as planning to ban exports of palm oil without ISPO certificates (Medan Bisnis Daily 2013). They support the MoA establishing and requiring mandatory ISPO certification (Sindo News 2014). The MoT will also provide incentives for ISPO certificate holders, like export tax reductions (BUMN 2014). The MoT and MoA are lobbying in Europe and other countries for the acknowledgement of ISPO certification. The MoT is negotiating ISPO in global trade forums like the World Trade Organisation since they are in charge, as the focal point of the World Trade Organisation (MoFA 2014). The Vice Minister of Trade argued that Indonesian palm oil companies that have the ISPO certification do not need the recognition of the RSPO certification (Nasionalisme 2014).

\section{Ministry of Industry (MoI)}

The development of industries downstream of the palm oil industry in Indonesia must be improved in order to increase added value. Indonesia is currently only able to produce about 47 derivative products from palm oil (MoI 
2012). This situation makes the MoI's position an important one in coalition with the MoA.

9 GAPKI (Indonesian Palm Oil Enterprise Association) This Indonesian private-business organisation was formed in 1981 (GAPKI 2014). As of 2013, GAPKI has 591 members, with a corresponding palm oil plantation area of around 3 million hectares, more than $30 \%$ of the Indonesian palm oil area, being an important government partner in improving the situation of Indonesian palm oil. GAPKI is also imposing the implementation of the Indonesian Sustainable Palm Oil (ISPO), which empowers Indonesia's sustainability-related regulation of palm oil production, especially for its members. In the beginning, GAPKI was registered as a member of the RSPO, but some GAPKI members argued that even though producers make up the biggest proportion of RSPO's membership, producer interests cannot be accommodated in the RSPO. Therefore GAPKI announced its resignation from the RSPO in 2011, and supported ISPO. The MoA used this momentum to strengthen the ISPO and may have complicated the national implementation of RSPO principles and criteria in Indonesia. GAPKI is an important actor that possesses power and influence to shape the ISPO as an instrument to reclaim authority over palm oil certification. GAPKI, as a non-state actor, has a limited formal ability to drive MoA outcomes, but it has ample capacity to enhance 'ISPO power'.

10 APKASINDO (Association of Indonesian palm oil farmers)

APKASINDO is a non-profit organization fighting for the rights of small-scale plantations in Indonesia (Exposenews 2009). In 1999, APKASINDO jointly with GAPKI sent a protest letter to RSPO after RSPO included reduce greenhouse gases as their indicator of assessment (Exposenews 2009). Even though this organisation supports ISPO they criticize the restrictions policy of concession palm oil business which only managed a maximum of 100,000 hectares (Ministry of Agriculture Regulation of 2013), claiming it will reduce investment of the palm oil sector affecting negatively the farmers (Sawit Indonesia 2013). This means also that this organisation mostly present their motives on taking advantages from governments actors and also private business actors. APKASINDO would like to strengthen GAPKI position on reinforcing ISPO's coalition for taking benefits from the beginning and rich ISPO incentives from government.

\section{RSPO}

RSPO respect domestic rules and regulations, including ISPO systems, therefore facilitating its Indonesian members' compliance with national rules, including ISPO systems. The Indonesian office of the RSPO will also facilitate application to the ISPO for its Indonesian firm members, they support ISPO for structural reasons not based on the basic interest.

\section{The UNDP(United Nations Development Programme)}

is successfully connecting the RSPO and the ISPO through a joint study programme (ISPO Commission 2013b; RSPO 2013). They also endorse the Sustainable Palm Oil initiative, along with Indonesian actors. This program will be coordinated by key actors such as the Ministry of Forestry, the Ministry of Environment, the Ministry of National Planning, Presidential Unit for Supervision and Development, the Agency of REDD+ (reduce emissions from deforestation and forest degradation, and foster conservation, sustainable management of forests, and enhancement of forest carbon stocks), the Ministry of Cooperatives and Small and Medium Enterprises, the National Land Agency, the Ministry of Trade, the National Standardization Agency, provincial and district governments, the private sector, smallholders, relevant palm oil associations, civil society (ISPO Commission 2013c). This initiative will be included or withdrawn from ISPO criteria after consideration by the ISPO Commission.

\section{Indonesian Palm Oil Board (DMSI)}

This institution is a non-state actor established based on article 19 Law Number 18 Year 2004 on Plantation. The goal of this institution is to mediate actors' interests to support palm oil for national income (DMSI 2009). Six palm oil enterprise associations and two directorate generals of the MoA are listed among these institutions. This institution focus on the industrialisation of palm oil, and the MoA supports them. The secretariat of this organisation is also housed in a MoA building near the ISPO Commission office. Information elements mean that this institution has power to conduct their formal responsibilities.

13 Indonesian Association of Biofuel Producers

This is a non-state actor, established to support the mandatory policy of the $10 \%$ biodiesel (Okezone 2013). Therefore this institution is allied to both the MoEMR and the MoA. Its element of power is the limited information on the enterprise of biofuels.

\section{Auditor}

They will benefit from the increased demand for both certification schemes. Some auditor providers prefer ISPO over RSPO because their indicator is much easier to be interpreted due to its indicator mainly to the domestic laws, so the Auditor will have a flexibility to decide and do not have much pressure from the state. To get certificate as an auditor, individual or company should pay about IDR3,500,000 until IDR16,000,000, which is conducted by ISPO Commission or other legalized agencies (ISPO Commission 2015; Training Centre 2015). Fundamentally, auditors work independently, but they have the discretion to test the 'doubtful' indicators (like social and environmental indicators) used in the assessment process, so there is a certain likelihood that they will provide a subjective assessment and even that their results could be affected by other actors' motives (Silva-Castañeda 2012). Only 7 independent audit organisations registered in 2003 and approximately 11 in 2014 accessed around 1200 palm oil firms in Indonesia (Agrofarm 2013a; East Kalimantan Plantation Agency 
2014). Both RSPO and ISPO require an independent auditor. Remarkably, some of the independent auditor organisations (like PT Sucofindo Persero, PT Mutuagung Lestari, PT TUV Rheinland Indonesia and PT SAI Global Indonesia) assess both RSPO and ISPO proposals for palm oil firms. Each has approximately 10 auditors.

\section{The RSPO Coalition}

\section{RSPO}

This global, multi-stakeholder organization's membership is comprised of $50 \%$ palm oil growers, $26 \%$ from palm oil processors and traders, $17 \%$ from organisations, $4 \%$ from conservation and environmental NGOs, 3\% from social and developmental NGOs, and $2 \%$ from good manufacturers (RSPO Indonesia Office 2014). This shows that palm oil growers and producers make up the biggest portion of the RSPO's membership, which is contrary to the Indonesian actors' assumption, i.e., that RSPO is much more representative of consumers' interests

\section{Big palm oil consumers}

Indonesian bureaucracies perceive the RSPO to be shaped mainly by consumer interests (Agrofarm 2014). Big palm oil consumers like Unilever, Anone, and Vollmar GmbH have membership in the RSPO (RSPO 2014a). Unilever announced their commitment to sustainable palm oil in the mid-1990s. It would seem that big palm oil consumer companies have settled their business and have chosen the voluntary scheme, due to the involvement and backing of environmental and social NGOs. The involvement of these NGOs contributed to the market legitimacy to strengthen demand actors' (big palm oil consumers) motives and positions to better struggle with supply actors' (Indonesian big palm oil producer) interests. Interestingly, this big palm oil company is not bothered with palm oil occupancy policy with a maximum of 100,000 ha and some other administrative and legality requirements. For example, SIPEF group who has a majority stake in 14 palm oil companies which is operated around 90 years in Indonesia through their Managing Director argued that this policy is not a big problem because 100,000 ha of palm oil is not easy any more to find in the recent plantation situation in Indonesia (Sawit Indonesia 2013c).

3 The commission of the European Union

Most European countries see climate change as a very serious problem. The European public has recognised the RSPO scheme as a respectable form of voluntary certification, particularly since RSPO RED would be the first voluntary certification to address climate change issues with regard to palm oil or this 'RSPO-RED has been approved by European Commission as a certification scheme accepted in compliance with the requirements of EU RED (Renewal Energy Directive) (RSPO 2014c). However, EU countries prefer RSPO over ISPO to ensure palm oil from Indonesia is 'efficiently' entering European countries, or a good strategy to challenge large numbers and cheap palm oil from Indonesia.

4 Environmental and social NGOs

We identified several NGOs that have strong concerns about serious unintended social and indigenous issues, and economic and environmental implications such as WWF, Rainforest Alliance, Oxfam and Sawit Watch (RSPO 2014b). Greenpeace Indonesia is an environmentalist NGO that exposes environmental problems and uses direct action, lobbying and research to achieve its goals. Greenpeace focuses its work on worldwide issues such as global warming and deforestation (Greenpeace 2011). Sawit Watch is a national NGO that chose to join the RSPO. Sawit Watch has been critical about environmental, human rights violations, labour and social issues (Sawit Watch 2014). They are very vocal and their message can often be distorted so as to be seen to be anti-palm, which confuses the issues sometimes.

5 Ministry of Agriculture (MoA)

The MoA also formally supports voluntary RSPO schemes for certain market purposes (Agroconsultant 2014). The Vice Minister of Agriculture said that the government does not deny the existence of the RSPO certification and that it is supposed to collaborate with the formation of a single palm oil certification in Indonesia (Bewara 2014). The Director of RSPO Indonesia Office proposed RSPO-ISPO cooperation starting with a joint audit. In addition, the Director General of Plantation of the MoA said the proposed joint audit of the certification process of the RSPO with that of the ISPO has the potential to reduce costs significantly (Tempo 2011). The former Minister of Forestry and Agriculture disagrees with some Indonesian actors that do not support the RSPO. He has now become an advisor on the RSPO board (RSPO 2011). This also shows that the RSPO tries to place an Indonesian ex-high level officer in a position that would strengthen their influence. In the informal mission, MoA hope that ISPO can be a pre requirement for RSPO standard (Antaranews 2013).

6 UNDPas well as Auditor

is also observed supporting RSPO coalition, and the detailed of this (actor's explanation has been described on the previous section (see Section ISPO coalition)

State certification established by regulatory power $\mathrm{A}$ bundle of regulations from the Ministry of Agriculture, the Ministry of Forestry, the National Land Agency, the Ministry of Environment was set up as a legal tool for ISPO standards and principles. This legality mechanism (Schouten \& Glasbergen 2011) is successful in collecting all power elements (coercive, incentive, and informational) from fragmented Indonesian bureaucracies to support the ISPO (Weber 1922; Krott et al. 2014). The use of regulatory power is similar with SVLK in Indonesian forestry sector (Wibowo et al. 2015 and Pratiwi et al. 2015). Even though Indonesia uses intensive regulatory power, it doesn't mean automatically have higher global legitimacy, but increase legitimacy contestation with RSPO (Marin Burgos et al. 
2014).

The meta governance system: Bureaucratic interests explaining who is favouring voluntary and mandatory and its intersection We expected through our research question that MoA favour ISPO schemes while MoT favour RSPO since the MoA created ISPO and MoT needs RSPO's existence for their successful negotiation of international certified palm oil. Surprisingly, all Indonesian bureaucracies support ISPO. This phenomenon shows that palm oil and ISPO have become a 'national interest' in Indonesian political bureaucracy. The ISPO, from the perspective of Indonesian bureaucracies, appears to be a tool serving the interests of producers, whereas the RSPO would seem to serve the consumers.

In addition, a new phenomenon shows that RSPO and ISPO are entering a collaboration effort that is also supported by International actors like the UNDP. Joint studies audits and even proposals for the formation of single certification schemes are indicative of both schemes assessing the situation and making decisions when this benefits both schemes, similar with Gulbrandsen (2014) that state-private relation has increase dynamic interactions but different on the politic of scaling (Hospes \& Kentin 2014).

Indonesian ministries seem to fully support the ISPO while they seem not to be against the RSPO. However, we also found that there is no 'real' actor opposing both the ISPO and the RSPO. These results show that pro ISPO and pro RSPO actors formally 'support' each other to shape their informal interests, that is contributed to the complex meta governance system. This phenomenon would lead the RSPO to assert their legitimacy over that of the ISPO in the future, which is in line with the argumentation by Overdevest \& Zeitlin (2012), that private certification will take back its legitimacy due to the trend from failed public governance to private experimentalism. In the end, the voluntary and the compulsory systems collaborate to attract global initiatives, shaping state and private interests. The ambiguity relations between states also indicate this meta-governance and private actors on making this jointly efforts, Mandatory certification have a critical orientation problem. If government orientation for protecting communities from environmental disaster, it can be accepted. But, if orientation of certification for legality of everything, its rather ambiguous, because if any certain company operate in certain country and the operation is illegal, it shows that the government cannot control their authority.

Non-state actors seem not to have enough roles in the state mandatory ISPO scheme. However, the RSPO accommodates them (like Sawit Watch and Greenpeace Indonesia). The involvement and backing up from NGOs as 'third pressure' contributed to the market legitimacy to strengthen RSPO' alliance. However, the ISPO is very confident since all state bureaucracies as well as some nonstate actors, like business and farmer associations support ISPO. This 'global-market-legitimisation' has a new a big challenge from 'domestic-state-legitimation' when the ISPO is introduced to attract powerful 'foreign states' and forces them to collaborate. This result supports our hypothesis that state mandatory schemes supported by state bureaucracies limit the influence of NGOs or private actors.

\section{Conclusion}

'Reclaiming' is the bureaucratic power process, shaped by state actors' interests, strongly and more successfully claiming back certification authority from private actors and show the trend of state hegemony. It is inline with Hospes \& Kentin (2014) that there is a significant role of state in palm oil certification. The state seems to force voluntary schemes to accept ISPO as complementary to the RSPO standard. This is ambiguous because some ISPO and RSPO standards conflict in the implementation of their principles especially on legal issues. This not only enforces the reclaiming process but also successfully establishes powerful standards through legal means that affirm the global trade governance mechanism. As the ISPO is not really replaces the RSPO, or ISPO intersect with RSPO has resulted to the complex palm oil meta governance similar with (Cashore \& Stone 2012) on investigating this private-state intersection. Finally, ISPO has to jointly collaborate with RSPO under UNDP facilitation to enlarge global market cover and increase their credibility over black campaign on illegal palm oil resources as well as social and environmental issues, it is inline with Willetts (2001) that governments are losing dominance when faced with the economic activities of transnational companies and the violent issues (Willetts 2001). In addition, we can observe how the complex meta governance becomes less complex, as national policies interconnect international institutional elements of the palm oil certification regime complex. We may also perceive it as 'less fragmentation" which is derived by the formal and informal cooperation from both coalition in the practical. The sovereignty of Indonesian actors to formulate mandatory certification has reduced the external interest pressure and provides flexibility to define each standard and indicator. Rather than fragmentation in private certification schemes, competition between private and public mandatory schemes resulted in their mutual adjustment and the increased accountability of schemes, which were simplified under the forms of legality of domestic sovereignty. Hence, our hypothesis that setting standards and indicators that serve the informal interest of state bureaucracies contribute to a less fragmented Indonesian tropical rainforest transformation regime complex is proved. Governing the government is the character of reclaiming tools and state hegemony, which will have a good impact on the global credibility if they can follow it thoroughly in the principle of good governance. This can be assessed in the future. Some strategic policy can be recommended such as strengthening the transparency of Environmental Impact Assessment and increasing public participation on monitoring ISPO implementation both in the policy making process and at application in the field. Furthermore, this 'national interest' is potentially to become a regional interest through ASEAN (Association of Southeast Asian Nations) regime, which is led by Indonesia, Malaysia, and Thailand which is now preparing for ASEAN sustainable palm oil certification schemes, and this domestic certification could potentially became a tools for restructuring palm oil industry sector to face ASEAN economic community. 


\section{Acknowledgements}

We greatly appreciate to financial support from DFG research project on the fragmentation of the international forest regime complex (PAK 813), the Eva Mayr-Stihl Foundation as well as Indonesian Government fund (DIKTI scholarship).

\section{References}

Agroconsultant. 2014. Peran Strategis ISPO dalam bisnis produk kelapa sawit .

Agrofarm. 2014. Perusahaan Kurang Siap, Susah Memperoleh ISPO. http://agroconsultant.asia/ perastrategis-ispo-dalam-bisnis-produk-kelapasawit.html. [04 June 2014].

Agrofarm. 2013a. ISPO Kekurangan Auditor. http://www.agrofarm.co.id/read/sawit/241/ispokekurangan-auditor/. [04 June 2014].

Agrofarm. 2013b. Indonesia Sungguh-Sungguh Menerapkan Standar Sustainability Palm Oil. http://www.agrofarm. co.id/read/sawit/264/indonesia-sungguhsungguhmenerapkan-stand ar-sustainability-palmoil/\#.U5AwGPmSxqU. [04 June 2014].

Antaranews. 2013. Kementan berharap ISPO jadi syarat $R S P O$. http://www.antaranews.com/berita/ 374033/kementan-berharap-ispo-jadi-syarat-rspo. [16 July 2014]

Aspinall E, Van Klinken G. 2011. The State and Illegality in Indo. Netherland: Brill. http://dx.doi.org/10.1163/ 9789004253681_002.

Bewara. 2014. SERTIFIKASI CPO, Kementan: Ada Peluang Digabungkan. http://bewara.co/read/2014/05/sertifikasicpo-kementan-ada-peluang-digabungkan/, Accessed on [17 July 2014]

Blackman A, Rivera J. 2011. Producer - Level Benefits of Sustainability Certification. Conservation Biology 25(6):1176-1185. http://dx.doi.org/10.1111/j.15231739.2011.01774.x.

BUMN. 2014. Perusahaan Sawit akan Mendapat Insentif. http://www.bumn.go.id/ptpn5/berita/10664/Perusahaan. sawit.akan.dapat.insentif. [04 June 2014].

Busch L. 2014. Governance in the age of global markets: challenges, limits, and consequences. Agriculture and Human Values 31(3):513-527. http://dx.doi.org/10. 1007/s10460-014-9510-x.

DMSI. 2009. http://dmsi.or.id/aboutus. [16 July2014].

Cashore B. 2002. Legitimacy and the privatization of environmental governance: How non-state market-driven (NSMD) governance systems gain rule-making authority. Governance 15(4):503-529. http://dx.doi.org/10.1111/1468-0491.00199.
Cashore B, Egan E, Auld G, Newsom D. 2007. Revising theories of nonstate market-driven (NSMD) governance: lessons from the Finnish forest certification experience. Global Environmental Politics 7(1):1-44. http://dx.doi.org/10.1162/glep.2007.7.1.1.

Cashore B, Stone MW. 2012. Can legality verification rescue global forest governance? Analyzing the potential of public and private policy intersection to ameliorate forest challenges in Southeast Asia. Forest policy and economics 18:13-22. http://dx.doi.org/10.1016/ j.forpol.2011.12.005.

Edwards DP, Laurance SG. 2012. Green labelling, sustainability and the expansion of tropical agriculture: critical issues for certification schemes. Biological Conservation 151(1):60-64. http://dx.doi.org/10. 1016/j.biocon.2012.01.017.

East Kalimantan Plantation Agency. 2014. http://disbun.kaltimprov.go.id/berita-497-penerapanispo-mundur-desember-2015.html. [25 June 2014].

Exposenews. 2009. Gapki dan Apkasindo Protes RSPO. http://eksposnews.com/view/7/8477/Gapki-danApkasindo-Protes-RSPO.html. [04 August 2014].

GAPKI. 2013. http://www.gapki.or.id/Page/Gapki Members?page $=4$.[30 June 2014].

GAPKI. 2014. http://www.gapki.or.id/Page/About. [04 June 2014].

Giessen L, Krott M, Möllmann T. 2014. Increasing representation of states by utilitarian as compared to environmental bureaucracies in international forest and forest-environmental policy negotiations. Forest Policy and Economics 38:97-104. http://dx.doi.org/ 10.1016/j.forpol.2013.08.008.

Giessen L, Burns S, Sahide MAK, Wibowo A. 2015.. From transnational governance to international government regimes in forest and agricultural certification: The key role of state bureaucracies for private governance in Argentina and Indonesia. Policy \& Society, under revision.

Gulbrandsen LH. 2014. Dynamic governance interactions: Evolutionary effects of state responses to non - state certification programs. Regulation \& Governance 8(1):74-92. http://dx.doi.org/10.1111/rego.12005.

Hospes O, Kentin A. 2014. Tensions Between Global - Scale and National-Scale Governance: The Strategic Use of Scale Frames to Promote Sustainable Palm Oil Production in Indonesia. Scale-Sensitive Governance of the Environment 203.

Hospes O. 2014. Marking the success or end of global multistakeholder governance? The rise of national sustainability standards in Indonesia and Brazil for palm oil and soy. Agriculture and Human Values 1-13. 
http://dx.doi.org/10.1007/s10460-014-9511-9.

Hsieh HF, Shannon SE. 2005. Three approaches to qualitative content analysis. Qualitative health research 15(9):1277-1288. http://dx.doi.org/10.1177/10497 32305276687 .

ISPO Commission. 2013a. http://www.ispoorg.or.id/index.php?option=com_content \&view=article \&id=93\&Itemid=271\&lang=en. [25 June 2014].

ISPO Commission. 2013b. http://www.ispoorg.or.id/index.php?option $=$ com_content $\&$ view $=$ article \&id=93\&Itemid=271\&lang=en. [25 June2014].

ISPO Commission. 2013c. http://www.ispoorg.or.id/index.php?option=com_content $\&$ view $=$ catego ry\&layout $=$ blog \&id=14\&Itemid $=219 \& \operatorname{lang}=e n$, Accessed on 25.06.2014.

ISPO commission, 2015. http://www.ispoorg.or.id/index.php?option=com_content \&view=article \&id=111:auditor-ispo-angk-16\&catid $=13 \&$ Itemid $=213$ \&lang=ina. [21 November 2015].

Krott M, Bader A, Schusser C, Devkota R, Maryudi A, Giessen L, Aurenhammer H. 2014. Actor-centred power: The driving force in decentralised community based forest governance. Forest Policy and Economics 49:34-42.

Krott M. 2005. Forest Policy Analysis. Dordrecht: Springer.

Larsen RK, Jiwan N, Rompas A, Jenito J, Osbeck M, Tarigan A. 2014. Towards 'hybrid accountability'in EU biofuels policy? Community grievances and competing water claims in the Central Kalimantan oil palm sector. Geoforum 54:295-305. http://dx.doi.org/10.1016/ j.geoforum.2013.09.010.

Marin-Burgos V, Clancy JS, Lovett J C. 2014. Contesting legitimacy of voluntary sustainability certification schemes: Valuation languages and power asymmetries in the Roundtable on Sustainable Palm Oil in Colombia. Ecological Economics.

Medan Bisnis Daily. 2013. Ekspor Sawit Tanpa ISPO akan Dilarang. http://medanbisnisdaily.com/news/read/2013/ 11/13/61507/ekspor_sawit_tanpa_ispo_akan_dilarang/ , [01 July2014].

McCarthy JF. 2012. Certifying in Contested Spaces: private regulation in Indonesian forestry and palm oil. Third World Quarterly 33(10):1871-1888. http://dx.doi.org /10.1080/01436597.2012.729721.

[MoA] Ministry of Agriculture. 2011. http://deptan.go.id/ sakip/admin/data2/LAKIP_DIR_PASCAPANEN_ 2011.pdf. [09 July 2014].

MoA Regulation 19 of 2011 on ISPO as mandatory for palm oil plantation firm in Indonesian. Peraturan Menteri
Pertanian No. 19/Permentan/OT.140/3/2011 tentang Kewajiban Sertifikasi ISPO Bagi Perusahaan Perkebunan. Jakarta: Ministry of Agriculture.

MoI. 2012. http://kemenperin.go.id/artikel/6372/IndustriSawit-Harus-Dibedakan-untuk-Makanan-danNonmakanan. [16 July 2014].

MoFA. 2014. Keanggotaan Indonesia pada Organisasi Internasional. http://kemlu.go.id/Documents/ Keanggotaan_Indonesia_pada_OI.pdf.[26 March2014].

[MoF] Ministry of Forestry. 2011. Indonesian Forestry Statistic in 2010. Jakarta: Ministry of Forestry.

[MoF] Ministry of Forestry. 2012. Indonesian Forestry Statistic in 2011. Jakarta: Ministry of Forestry.

[MoF] Ministry of Forestry. 2013. Indonesian Forestry Statistic in 2012. Jakarta: Ministry of Forestry.

Mosley L. 2013. Introduction. "Just Talk to People"? Interviews in Contemporary Political Science. In: Mosley L, Editor. Interview Research in Political Science. London: Cornell University Press.

Nasionalisme. 2014. http://www.nasionalisme.co/?p=895. [18 July 2014].

Neuman WL. 2005. Social research methods. Quantitative and qualitative approaches. $6^{\text {th }}$ edition. London, UKAllyn and Bacon.

Niskanen W. 1971. Bureaucracy and Representative Government. Aldine-Atherton, Chicago

Okezone. 2013. Asosiasi Biofuel Dukung Kebijakan 10\% Biodiesel. http://economy.okezone.com/read/2013/09/ 17/19/867622/asosiasi-biofuel-dukung-kebijakan-10biodiesel, Accessed on 16.07.2014.

Overdevest C, Zeitlin J. 2012. Assembling an experimentalist regime: Transnational governance interactions in the forest sector. Regulation \& Governance 8(1):22-48.

Pattberg P. 2012. Transnational Environmental Regimes. In: F. Biermann, P. Pattberg, editors. Global Environmental Governance Reconsidered. Cambridge: MIT Press.

Pratiwi S, Wibowo A, Giessen L. 2015. Third-Party Certification of Forest Management In Indonesia: Analysing Stakeholders' Recognition and Preferences. Jurnal Manajemen Hutan Tropika 21(2):65-75. http://dx.doi.org/10.7226/jtfm.21.2.65.

Pesqueira L, Glasbergen P. 2013. Playing the politics of scale: Oxfam's intervention in the Roundtable on Sustainable Palm Oil. Geoforum 45:296-304. http://dx.doi.org/10.1016/j.geoforum.2012.11.017.

Peters BG. 2010. The Politics of Bureaucracy-An Introduction to Comparative Public Administration. 
Sixth edition. Routledge. Oxon

Pratiwi S, Wibowo A, Giessen L. 2015. Third-party certification of forest management in Indonesia: Analysing stakeholders' recognition and preferences. Journal Manajemen Hutan Tropika 21(2):65-75. http://dx.doi.org/10.7226/jtfm.21.2.65.

Rametsteiner E, Simula M. 2003. Forest certification-an instrument to promote sustainable forest management? Journal of environmental management 67(1):87-98. http://dx.doi.org/10.1016/S0301-4797(02)00191-3.

Raustiala K, Victor DG. 2004. "The Regime Complex for Plant Genetic Resources," International Organization 55:277-309. http://dx.doi.org/10.1017/s00208183045 82036 .

RSPO. 2014a.http://www.rspo.org/en/certified_grower, [ 04 June 2014].

RSPO. 2014b. http://www.rspo.org/en/member/listing/ category/Consumer\%20Goods\%20Manufacturers. [16.July 2014].

RSPO. 2014c. http://www.rspo.org/en/rspo-red_briefing for_members. [14August 2014].

RSPO. 2013. ISPO and RSPO enter into strategic cooperation. http://www.rspo.org/news_details.php? nid=195. [09 July 2014].

RSPO. 2012. http://www.rspo.org/en/member/23/pt-pplondon-sumatra-indonesia-tbk. [30 June 2014].

RSPO. 2011. RSPO Tunjuk Mantan Menteri Pertanian dan Kehutanan Bungaran Saragih Sebagai Penasehat. http://www.rspo.org/news_details.php?nid=13\&lang=5. [17 July 2014].

Sahide MAK, Giessen L. 2015. The fragmented land use administration in Indonesia-Analysing bureaucratic responsibilities influencing tropical rainforest transformation systems. Land Use Policy 43:96-110. http://dx.doi.org/10.1016/j.landusepol.2014.11.005.

Sawit Indonesia. 2013. Investasi Hulu Sawit Semakin Tertekan 2(25): 18-20

Sawit Watch. 2014. http://sawitwatch.or.id/2011/09/sawit-
watch-and-rspo/\#sthash.OmrmjTFB.dpuf. [04 July 2014.

Sindo News. 2014. http://ekbis.sindonews.com/read/ 856224/34/kemendag-gencarkan-sertifikasi-ispo-untukpetani-sawit. [09 July 2014].

Schouten G, Glasbergen P. 2011. Creating legitimacy in global private governance: The case of the Roundtable on Sustainable Palm Oil. Ecological economics 70(11):1891-1899. http://dx.doi.org/10.1016/j.ecole con.2011.03.012.

Sikor T, Auld G, Bebbington AJ, Benjaminsen TA, Gentry BS, Hunsberger C, Izac A, Margulis ME, Plieninger T, Schroeder H, Upton C. 2013. Global land governance: from territory to flow? Current Opinion in Environmental Sustainability 5(5):522-527. http://dx.doi.org/10.1016/ j.cosust.2013.06.006.

Silva-Castañeda L. 2012. A forest of evidence: third-party certification and multiple forms of proof - a case study of oil palm plantations in Indonesia. Agriculture and Human Values 29(3):361-370. http://dx.doi.org/10.1007/ s10460-012-9358-x.

Tempo. 2011. Pemerintah Pertimbangkan Audit Gabungan Sertifikasi Sawit. http://bisnis.tempo.co/read/news/2011 /05/19/090335482/pemerintah-pertimbangkan-auditgabungan-sertifikasi-sawit [17 July 2014].

Training Centre. 2015. http://www.trainingcenter. co.id/audit-rspo-ispo. [21November 2015].

Van Evera S. 1997. Guide to methods for students of political science. Cornell University Press.

Weber M. 1922. Wirtschaft und Gesellschaft. Grundriß der verstehenden Soziologie. Studienausgabe. Zitiert nach der Ausgabe von 1988. Tübingen.

Wibowo A, Sahide MAK, Dharmawan B, Pratiwi S, Giessen L. 2015. Global forest certification schemes in Indonesia and their transformation options. Risalah Kebijakan Pertanian dan Lingkungan 2(1):1-8.

Willetts P. 2001. Transnational actors and international organizations in global politics. The globalization of world politics, 2 . 